\title{
水蓄熱と組み合わせた躯体蓄熱空調システムのエネルギー評価に関する研究 A STUDY ON THE ENERGY EVALUATION OF THE BUILDING THERMAL MASS STORAGE SYSTEM WITH THE CHILLED WATER STORAGE SYSTEM
}

\author{
中 村 卓 司*，長野 克 則**，金田一 清香*** \\ Takuji NAKAMURA, Katsunori NAGANO and Sayaka KINDAICHI
}

\begin{abstract}
In this paper the energy characteristics of the building thermal mass storage system with the chilled water storage system is evaluated. A typical commercial building model is simulated by a computer and the influence of the regions, the daily weather and the heat load in the room is examined. The results show that the increase rate of the cooling load and the electricity consumption is high in the months of the low cooling load comparing with the non-storage case. And the building thermal mass storage system with the water storage reduces the primal energy consumption by $2.7 \%$ and the exhaust carbon dioxide by $10.4 \%$ in the optimized case in Tokyo.
\end{abstract}

Keywords: building thermal mass storage, chilled water storage, evaluation of primary energy consumption 躯体蓄熱，水蓄熱，一次エネルギー評価

\section{1. はじめに}

近年、建築躯体に蓄熱を行う躯体蓄熱空調システムが、従来の水 や水を用いた蓄熱システムと同様に負荷平準化に役立つものとして 検討されている。躯体蓄熱は建物内に既に存在するコンクリートス ラブなど建築躯体を蓄熱体とすることで大きな初期コストを必要と せず、水や水の蓄熱槽や空調機の容量を削減でき、夜間電力の利用 によって経済性、環境性も向上可能であるといったメリットが指摘 される一方で、その負荷平準化の有効性や省エネルギーに対して外 気温など気象条件による影響、地域特性など不明瞭な点も少なくな い。特に、夜間建物で蓄熱を行うことによる熱損失、空調機、ポン プなど空調機器の運転時間延長による搬送動力の増加などのデメリ ットが考えられる。さらに現在の躯体蓄熱の運用においては水蓄熱 や氷蓄熱など他の蓄熱システムとの併用を行っている場合が多いた め、組み合わせた検討も必要である。

これらの課題に対してはシミュレーションによる検討が考えられ るが、過去のシミュレーションによる躯体蓄熱の研究では長井 ${ }^{1)} に$ よりパッケージ空調機を用いた躯体蓄熱において空調運転の最適化 について検討されている。また、盧・宇田川 ${ }^{2)}$ により空調機を用い た躯体蓄熱において内部発熱、外乱の影響による性能検討が行われ ている。しかしながら、蓄熱の検討は躯体蓄熱部分にとどまり実運 用で多い、他の蓄熱との組合せの影響、性能には踏み込まれていて いない。他の蓄熱システムとの組合せでは相楽・三浦 ${ }^{3)}$ により実測 とシミュレーションによる検討が行われているが、対象となる蓄熱
システムは氷蓄熱パッケージ空調機となっている。

本論文ではセントラル型の空調システムを検討対象とし、併用す る蓄熱システムとしては一般的な水蓄熱を選び、冷房の期間シミュ レーションを実施して性能の検討評価を行った。また、空調方式と しては躯体蓄熱に適していると考えられる全面床吹出し空調システ ムを対象とした。パラメータとしては、地域特性とし、札幌、仙台、 東京、鹿児島の 4 都市を選び、東京に関しては室発熱密度を 2 段階 設定した。また、建物の断熱性の影響、蓄熱時間に関する検討を行 った。

\section{2. 検討対象システム}

\section{1 対象建物概要}

検討対象建物は図 1 に示寸日本建築学会のオフィス用標準問題 ${ }^{4)}$ にある建物とした。このうち基準階の事務室の一室の二次元空間を 計算対象領域とした。空ガラス、ブラインドおよび外壁の各物性值 は文献にある標準值を使用した。空ガラスの熱貫流率 $7.4 \mathrm{~W} / \mathrm{m}^{2} / \mathrm{K}$ 、 外壁の熱貫流率 $1.0 \mathrm{~W} / \mathrm{m}^{2} / \mathrm{K}$ となる。室寸法は奥行き $12.3 \mathrm{~m}$ 、天井高 $2.6 \mathrm{~m}$ で、計算領域の幅は単位長とし、外壁側は空面積率を $30 \%$ と した。床はコンクリートスラブ $120 \mathrm{~mm}$ の上に $150 \mathrm{~mm}$ の二重床を設 けた。二重床は $22 \mathrm{~mm}$ のコンクリート製の $\mathrm{OA}$ フロアパネルと $5 \mathrm{~mm}$ のタイルカーペットから構成される。気象条件は拡張アメダス気象 データを用いて外気温と日射量を与えた。空ガラスは反射率 7\%、 吸収率 $18 \%$ 、透過率 $75 \%$ とした。

\footnotetext{
* 清水建設(侏技術研究所工修

** 北海道大学大学院工学研究科 教授. 工博

*** 東京大学大学院工学研究科 助教 $\cdot$ 博士 (工学)
}

Institute of Technology, Shimizu Corporation, M. Eng.

Prof., Graduate School of Engineering, Hokkaido University, Dr. Eng.

Research Assoc., Graduate School of Engineering, The University of Tokyo, Dr. Eng. 


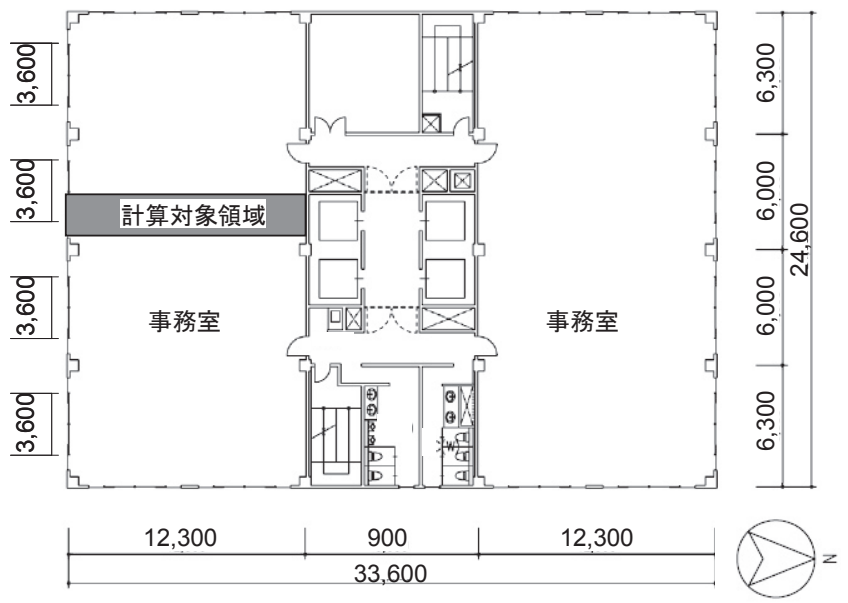

図 1 検討対象事務所ビル平面図

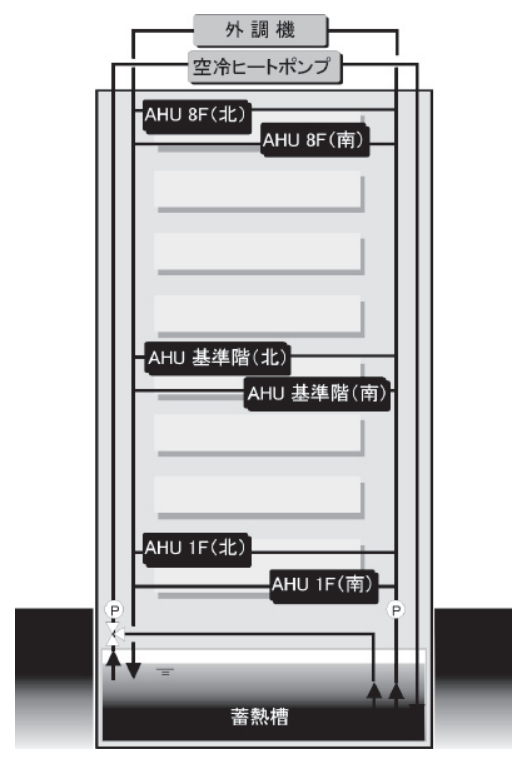

図 2 空調システム系統図

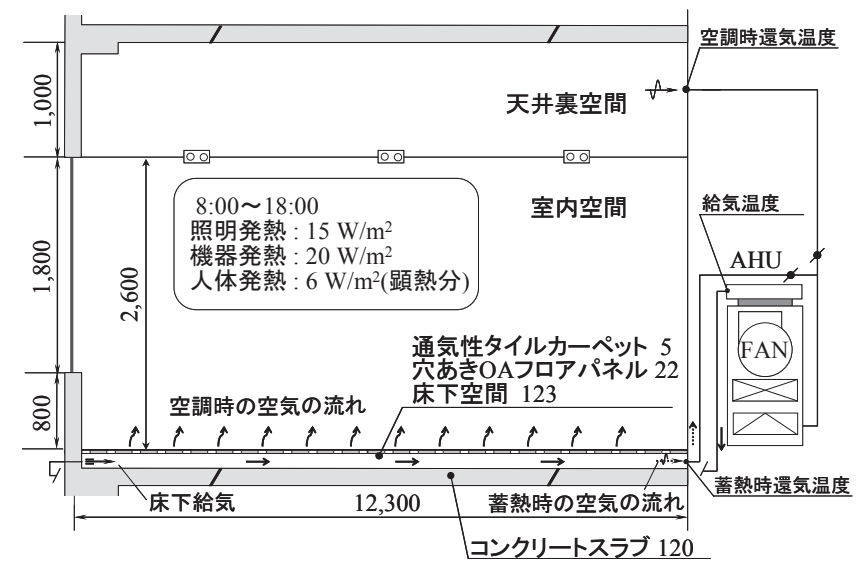

図 3 検討対象室の断面

\section{2 空調システム概要}

熱源は空冷ヒートポンプチラーとし、各階 2 つの事務室に各々 1 台の空調機を設置する。外気導入は建物全体でまとめて 1 台の外調 機を設け、外気負荷と在室者の潜熱負荷分をあらかじめ処理した後、 ダクトで各空調機へ送るものとした。また、蓄熱ケースでは躯体蓄
熱に加えて水蓄熱システムを与えた。図 2 に空調系統図を示す。

空調方式は全面床吹出し空調システムとした。図 3 に示すように 空調時は各事務室に設置された空調機から二重床内に給気し、穴あ き $\mathrm{OA}$ フロアパネルと通気性タイルカーペットを通り、床全面から 室内に微風速で供給される。蓄熱時は二重床内に冷気を循環させコ ンクリートスラブと OA フロアパネルに蓄熱した後、床下より還気 される。

\section{3. 躯体蓄熱部分の検討}

\section{1 計算プログラム}

計算には武田 ${ }^{5)}$ らによる計算プログラムを用いた。本プログラム は粒状潜熱蓄熱材を用いた躯体蓄熱計算プログラムであるが、全面 床吹出し空調を用いた躯体蓄熱空調システムをべースとしているた め潜熱蓄熱材量をゼロとすることで躯体蓄熱計算を行うことができ る。プログラムの妥当性は実験室実験との検証 ${ }^{5)}$ で行われているた め、今回は計算条件のみを変えて計算を行った。

\section{2 計算条件とシミュレーションケース}

昼間の空調時間（以下、空調時）は 8:00 から 18:00 とし、空調時 間帯に室内発熱負荷を与えた。室内発熱負荷は、在室者数を 0.1 人 $/ \mathrm{m}^{2}$ として人体発熱(顕熱分) $6 \mathrm{~W} / \mathrm{m}^{2}$ 、機器発熱 $20 \mathrm{~W} / \mathrm{m}^{2}$ 、照明発熱 $15 \mathrm{~W} / \mathrm{m}^{2}$ の合計 $41 \mathrm{~W} / \mathrm{m}^{2}$ とした。計算は比較のため躯体蓄熱ケースと 非蓄熱ケースについて実施した。躯体蓄熱ケースでは現状の電力料 金体系を参考に躯体による蓄熱量が水蓄熱量を超えないようにする ため 22:00 から 3:00 までの 5 時間を水蓄熱運転、3:00 から 8:00 まで の 5 時間を躯体蓄熱運転とした。また、22:00 から 8:00までを夜間、 8:00 から 22:00 までを昼間と分類した。3:00 からの躯体蓄熱時間 (以 下、蓄熱時) は $13^{\circ} \mathrm{C}$ 給気、最大風量で二重床内を循環し蓄熱を行い、 蓄熱終了の 8:00 まで蓄熱運転を行った。空調時の空調機の制御は設 定室温 $26^{\circ} \mathrm{C}$ に対する変風量制御とし、最大風量 $30 \mathrm{~m}^{3} / \mathrm{h} / \mathrm{m}^{2}$ 、最小風 量 $5 \mathrm{~m}^{3} / \mathrm{h} / \mathrm{m}^{2}$ 、最低吹出し温度 $19^{\circ} \mathrm{C}$ と設定した。

シミュレーションケースは地域性を考慮し、札幌、仙台、東京、 鹿児島の 4 都市について計算を行った。さらに、近年増加している 室内発熱が高いケースを東京で設定した。このケースのみ室内発熱 を人体 $12 \mathrm{~W} / \mathrm{m}^{2}$ 、機器 $30 \mathrm{~W} / \mathrm{m}^{2}$ 、照明 $20 \mathrm{~W} / \mathrm{m}^{2}$ の合計 $62 \mathrm{~W} / \mathrm{m}^{2}$ とした。 また、計算期間である冷房期間は 5 月 1 日から 10 月 31 日とし、土 曜日、日曜日は休日と考え非空調日とした。また、計算助走期間は 7 日間とした。

\section{3 結果と考察}

\section{3.1 シミュレーション結果概要}

まず、東京のピーク日（7月 31 日）を代表として躯体蓄熱の性状 の分析を行った。図 4 は東京ピーク日の室温、給還気温度、風量の 経時変化である。室温は躯体蓄熱開始の $28.2^{\circ} \mathrm{C}$ から $24.7^{\circ} \mathrm{C}$ まて低下 しているが空調開始とともに設定室温の $26^{\circ} \mathrm{C} に$ 保たれている。予冷 が不要で立ち上がり特性が良いという躯体蓄熱のメリットの一つが 表れている。給気温度は蓄熱時は $13^{\circ} \mathrm{C} 、$ 空調時は空調開始直後を除 き $19^{\circ} \mathrm{C}$ で給気を行っている。風量は蓄熱時は最大風量で給気し、空 調時は負荷に合わせて変動している。

次に躯体蓄熱量の算出の基となる躯体温度の経時変化を図 5 に示 
す。本論文では蓄熱対象部位をコンクリートスラブと $\mathrm{OA}$ フロアパ ネルとし、図中の温度は対象部位の平均温度を表している。また、 躯体温度は休日の影響をみるためピーク日を含む一週間の変化を示 した。休日明けの 7 月 31 日では蓄熱時の温度低下がスラブ $3.1^{\circ} \mathrm{C} 、$ $\mathrm{OA}$ フロアパネル $6.5^{\circ} \mathrm{C}$ となるのに対し、空調時の温度上昇はスラブ $0.0^{\circ} \mathrm{C} 、 \mathrm{OA}$ フロアパネル $1.4^{\circ} \mathrm{C}$ とり、スラブは放熱に寄与していな い。これは休日中の躯体温度上昇による蓄熱負荷を処理しているた めと考えられる。金曜日にあたる 8 月 4 日の結果では、蓄熱時の温 度低下がスラブ $2.2^{\circ} \mathrm{C} 、 \mathrm{OA}$ フロアパネル $4.5^{\circ} \mathrm{C}$ に対し、空調時の温 度上昇はスラブ $2.0^{\circ} \mathrm{C} 、 \mathrm{OA}$ フロアパネル $3.9^{\circ} \mathrm{C}$ であり、蓄熱分のほ とんどを空調時に放熱している。

次に躯体蓄熱ケースと非蓄熱ケースの空調機負荷の経時変化の比 較を図 6 に示寸。空調時の棒グラフ中の横線、縦線の部分が躯体か らの放熱で非蓄熱との差になり、躯体蓄熱の効果となる。躯体蓄熱 による効果は空調開始時から午前中は比較的大きいものの午後は効 果が小さくなる。躯体からの放熱の方向では横線で示す給気側であ る上階への放熱が大部分を占めている。また、図 5 において休日明 けの月曜日は休日の蓄熱負荷により、スラブが放熱に寄与していな いと述べたが、図 6 において非蓄熱ケースと比較して蓄熱の効果が 現れているのは、非蓄熱ケースにおいても休日の蓄熱負荷があるた めと考えられる。

最後に図 7 に躯体蓄熱の効率を算出した結果を示して、今回のシ ステムの性能を検証する。まず、夜間投入熱量のうちどれだけ有効 に躯体蓄熱されたかを示す蓄熱投入熱量比率注 ${ }^{1)}$ は月曜日から金曜 日まで $85 \%$ 以上の高い值を示した。通常は $70 \%$ 以上といわれている ので今回のシステムは効率の良いシステムであることが確認された。 次に夜間投入熱量が非蓄熱ケースと比較して昼間の空調負荷削減に どれだけ寄与したかを示す蓄熱効率注2) は月曜日が $71 \%$ と小さいも のの火曜日以降は $90 \%$ 以上で蓄熱の投入熱量が昼間の負荷削減に 有効に寄与しているといえる。ピークシフト率注 3) は非蓄熱ケース に比べてどれだけ昼間の空調負荷を削減できたかを示す負荷平準化 指標であるが、月曜日が最も小さく $29 \%$ 、水曜日が最も高く $56 \%$ で 週の平均で $44 \%$ であった。躯体蓄熱より顕熱負荷の 4 割が夜間に移 行できている。

\section{3. 2 昼夜空調機負荷ならびに空調機負荷増加率の地域と月別の} 比較

次に、月別の特性をみるため図 8 に東京ケースの空調機負荷積值 と非蓄熱ケースに対する負荷増加率をまとめたグラフを示す。図中、 棒グラフが蓄熱ケースの昼夜別空調機負荷積算值、 $\square$ 印の折れ線が 非蓄熱ケースの空調機負荷積算值、○印の折れ線が非蓄熱ケースに 比べた負荷増加率である。全体的な傾向としていえることは、 5 月、 6 月、10月の中間期で非蓄熱ケースに比べた負荷増加率が大きいと いうことである。そこで、次に地域別の特性を検討するため各ケー スの月別の負荷増加率を表 1 にまとめた。これによると、特に札幌、 仙台の 5 月、6 月、10月の結果は $25 \%$ を超え大幅な負荷増加となっ ている。これは中間期では空調機負荷の絶対值が小さくなり相対的 に増加率が大きくなるという要因もあるが、躯体蓄熱による夜間負 荷だけで非蓄熱ケースの昼間負荷にせまり、熱損失が大きくなると 思われる。そのため、負荷増加率の点からすると空調機負荷の小さ

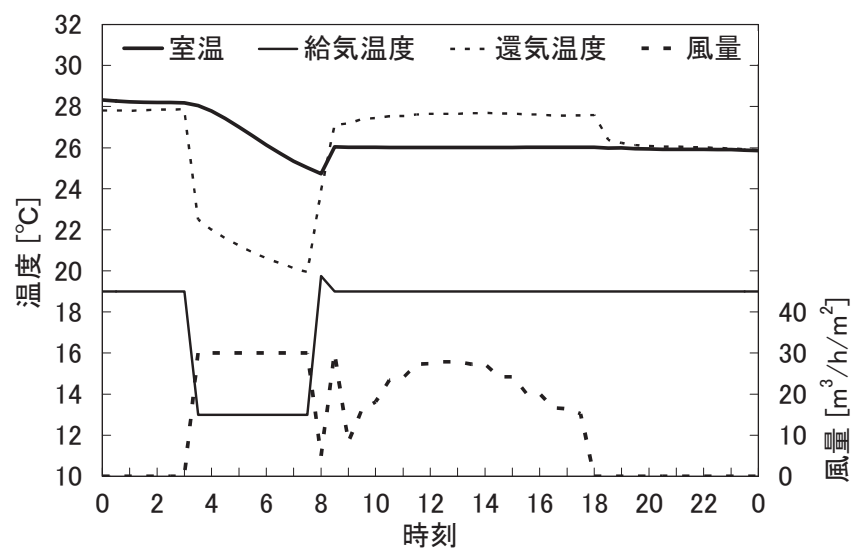

図 4 ピーク日における室温、給還気温度、風量の経時変化（東京）

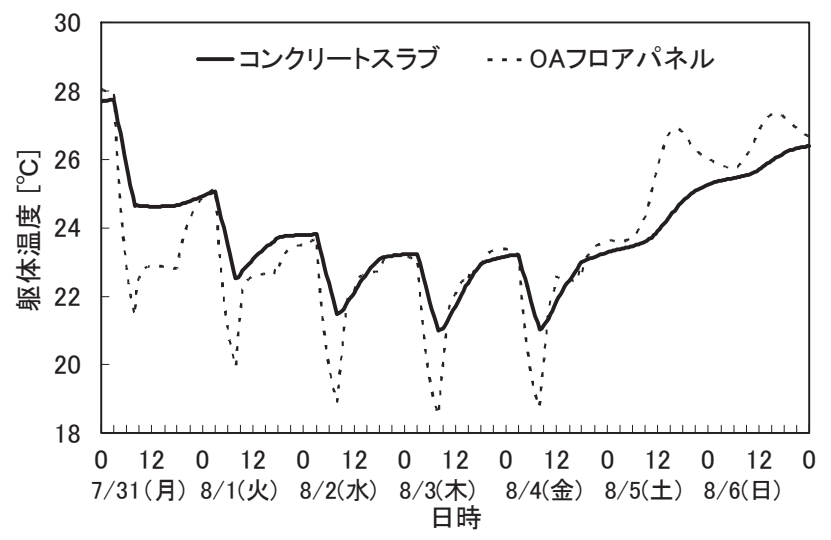

図 5 ピーク週の躯体温度の経時変化（東京）

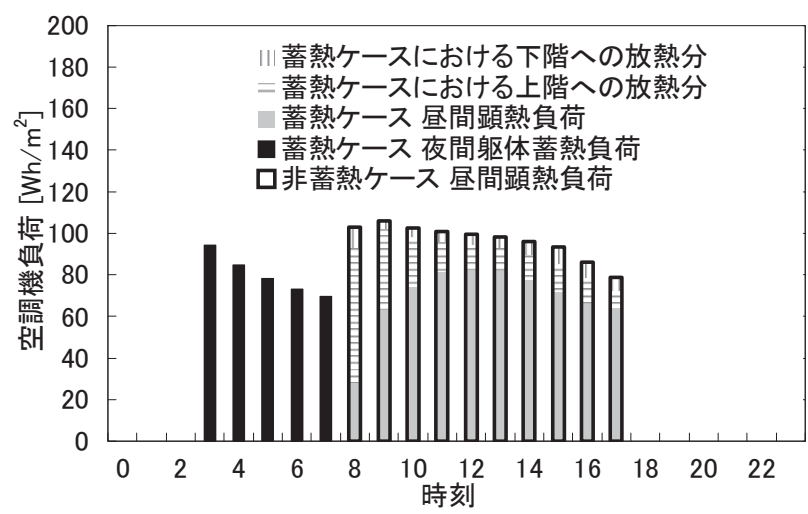

図 6 ピーク日の空調負荷の経時変化（東京）

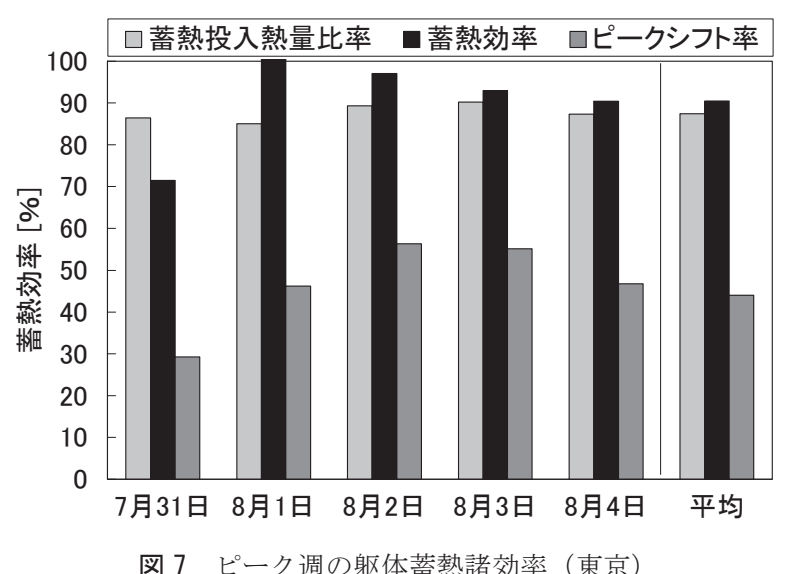

図 7 ピーク週の躯体蓄熱諸効率（東京） 


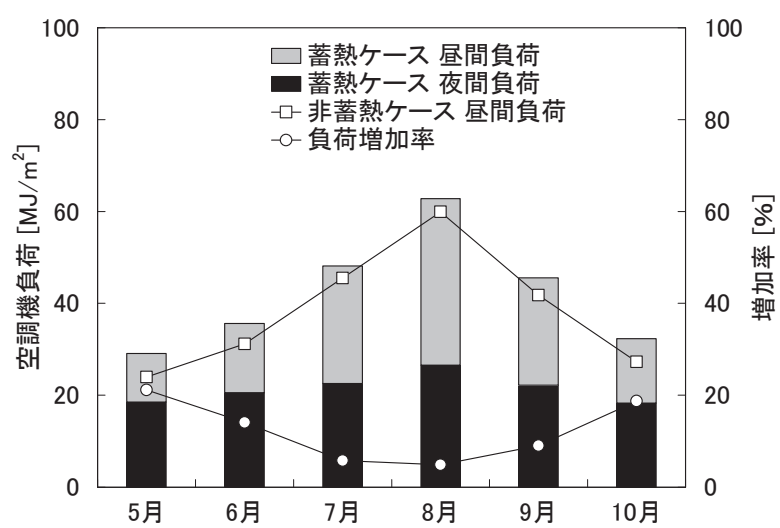

図 8 月別の空調機負荷積算値と負荷増加率（東京）

表 1 地域別、月別の空調機負荷増加率

\begin{tabular}{|c|r|r|r|r|r|}
\hline & \multicolumn{1}{|c|}{ 札幌 } & \multicolumn{1}{c|}{ 仙台 } & \multicolumn{1}{c|}{ 東京 } & 鹿児島 & 東京(高負荷) \\
\hline 5月 & 118.3 & 57.0 & 21.2 & 15.3 & 9.3 \\
\hline 6月 & 36.3 & 29.4 & 14.1 & 8.8 & 5.6 \\
\hline 7月 & 13.5 & 12.5 & 5.8 & 4.6 & 3.7 \\
\hline 8月 & 6.8 & 4.6 & 4.9 & 3.5 & 3.2 \\
\hline 9月 & 13.1 & 11.8 & 9.0 & 5.0 & 3.7 \\
\hline 10月 & 86.9 & 34.7 & 18.7 & 6.7 & 7.2 \\
\hline 期間平均 & 23.4 & 17.5 & 10.4 & 6.4 & 5.0 \\
\hline
\end{tabular}

な時期の躯体蓄熱は行わないほうが良いといえる。全冷房期間で比 較すると負荷増加率は札幌 $25.3 \%$ 、仙台 $17.9 \%$ 、東京 $10.5 \%$ 、鹿児 島 $6.3 \%$ 、東京の高室内発熱ケース $5.0 \%$ となる。空調機負荷が大き くなると負荷増加率は小さくなるが、東京と鹿児島の地域による違 いよりは、同じ東京で室内発熱が高いケースの方が負荷増加率は小 さくなる。東京の高室内発熱ケースでは全冷房期間で負荷増加率が 10\%以下となっている。

\section{4. 空調システム全体での消費エネルギーの検討}

\section{1 空調システムの設定条件と計算条件}

空調システムは図 2 に示寸空冷ヒートポンプチラーを熱源とする 水蓄熱システムとした。建物負荷の算出は前章で求めた躯体蓄熱の 顕熱負荷に外気導入負荷を加えた。外気導入負荷は 9:00 から 18:00 まで $5 \mathrm{~m}^{3} / \mathrm{h} / \mathrm{m}^{2}$ 与えるものとし、別途冷房期間分算出した。建物全体 での空調機負荷（顕熱負荷）の算出は前章の単位面積当たり結果を 全空調ゾーンに適用するものとし、建物全体の空調面積 $4,880 \mathrm{~m}^{2}$ を 乗じた。設備容量としては、熱源は東京の建物負荷を参考にメーカ 一カタログより定格泠却能力 $265 \mathrm{~kW}$ の機種を選び、各々のケースで 必要台数分を与えた。表 2 に熱源機の仕様を示寸。また、部分負荷 時は容量制御を行うものとし、文献 $\left.{ }^{6}\right)$ にある部分負荷特性と外気温 度補正を与えた。図 9 に外気温度特性、図 10 亿部分負荷特性を示寸。 躯体蓄熱用にはどのケースも 2 台必要となったため、水蓄熱槽の容 量は $265 \mathrm{~kW}$ の空冷ヒートポンプチラー2 台が 22:00 から 3:00 までの 5 時間運転する容量 $2,650 \mathrm{kWh}$ を与え、蓄熱槽効率は 1 、熱損失は無 いものとした。利用温度差を $5^{\circ} \mathrm{C}$ とすると、水槽容量は $455.8 \mathrm{~m}^{3}$ とな る。蓄熱時の熱源機の運転は、躯体蓄熱計算でも述べたが同一の熱 源機を 22:00 から 3:00 までの 5 時間を水蓄熱運転、3:00 から 8:00 ま での 5 時間を躯体蓄熱運転とした。空調ゾーンは各階の事務室を 1 ゾーンと考え空調機を 1 台設置するものとした。1 ゾーンの空調面
表 2 空冷ヒートポンプチラー仕様

\begin{tabular}{|l|c|}
\hline 定格泠却能力 & $265.0 \mathrm{~kW}$ \\
\hline 定格消費電力（補機含む） & $92.1 \mathrm{~kW}$ \\
\hline
\end{tabular}

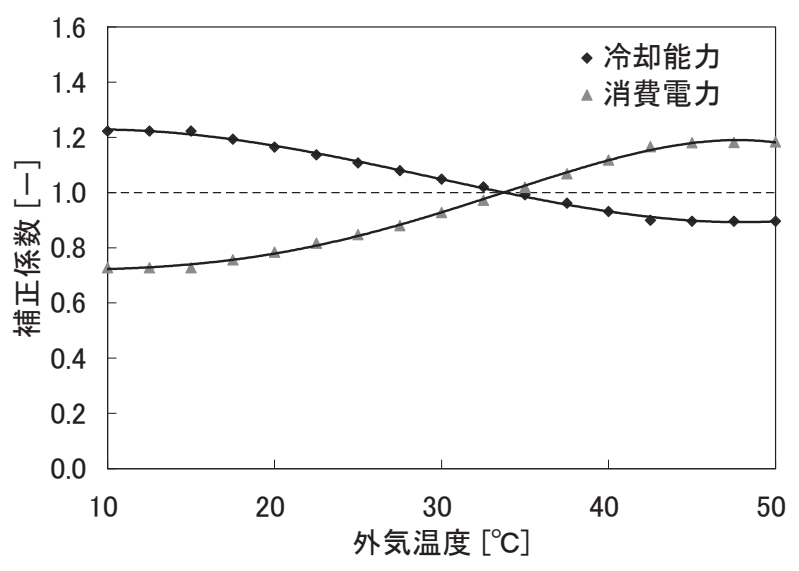

図 9 空冷ヒートポンプチラーの外気温度特性

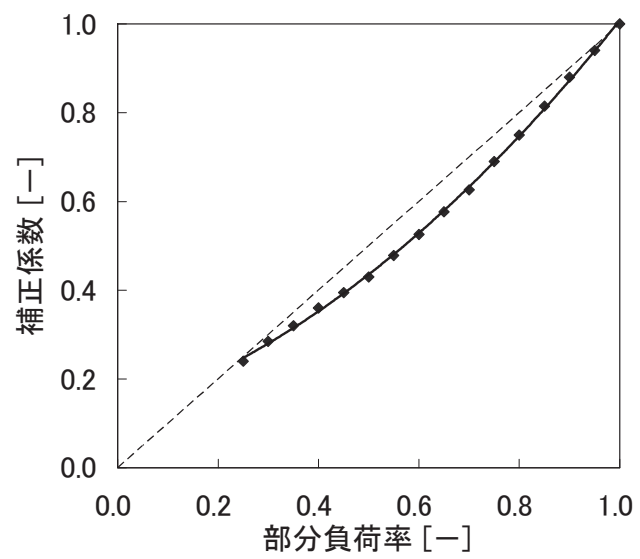

図 10 空冷ヒートポンプチラーの部分負荷特性

表 3 システム仕様の比較

\begin{tabular}{|c|c|c|}
\hline & 非蓄熱システム & 蓄熱システム \\
\hline 空調方式 & \multicolumn{2}{|c|}{ 全面床吹出し方式 } \\
\hline \multirow{2}{*}{ 熱源機 } & \multicolumn{2}{|c|}{ 空冷ヒートポンプチラー } \\
\hline & 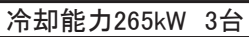 & 冷却能力 265kW 2台 \\
\hline 水蓄熱槽 & \begin{tabular}{|c|lll} 
無L \\
\end{tabular} & $455.8 \mathrm{~m}^{3}(2,650 \mathrm{kWh})$ \\
\hline ポンプ & \multicolumn{2}{|c|}{$109.5 \mathrm{~m}^{3} / \mathrm{h}$ 、全揚程 $250 \mathrm{kPa}$} \\
\hline 空調機 & \multicolumn{2}{|c|}{ 風量 $9,150 \mathrm{~m}^{3} / \mathrm{h}$ 、全圧差 $381 \mathrm{~Pa}$} \\
\hline 水蓄熱 & 無し & 22:00 3:00、5時間 \\
\hline 躯体蓄熱 & 無L & 3:00 8:00、5時間 \\
\hline
\end{tabular}

積は $305 \mathrm{~m}^{2}$ であるので最大風量 $30 \mathrm{~m}^{3} / \mathrm{h} / \mathrm{m}^{2}$ の能力を持ったファン動 力を与え、回転数制御による変風量を考慮して動力を算出した。フ アン動力は定格值を理論式より求め、部分負荷時の動力はファンの 回転数制御特性 ${ }^{6}$ を与えて算出した。ポンプは各ケースとも非蓄熱 ケースの建物負荷の最大負荷を用いて理論式より定格值を与え、部 分負荷時はポンプの回転数制御特性 ${ }^{\text {) }}$ を与えて動力を算出した。ま た、表 3 に非蓄熱ケースと蓄熱ケースのシステム仕様の一覧を示す。 比較のため行った非蓄熱ケースは水蓄熱、躯体蓄熱とも行わない全 くの非蓄熱ケースとした。 
表 4 月別の電力消費量と非蓄熱に対する増加率（札幌）

\begin{tabular}{|c|c|c|c|c|c|c|c|c|c|}
\hline & \multicolumn{2}{|c|}{ 空冷ヒートポンプ } & \multicolumn{2}{|c|}{ 空調機 } & 外調機 & \multicolumn{2}{|c|}{ ポンプ } & \multirow{2}{*}{ 合計 } & \multirow{2}{*}{ 増加率 } \\
\hline & 昼間 & 夜間 & $\begin{array}{l}\text { 昼間 } \\
\end{array}$ & 夜間 & 昼間 & 昼間 & 夜間 & & \\
\hline & kWh & $\mathrm{kWh}$ & $\mathrm{kWh}$ & kWh & $\mathrm{kWh}$ & $\mathrm{kWh}$ & $\mathrm{kWh}$ & kWh & $\%$ \\
\hline 5月 & 0 & 3,959 & 827 & 2,695 & 1,630 & 221 & 141 & 9,473 & 80.1 \\
\hline 6月 & 0 & 5,702 & 996 & 2,695 & 1,630 & 225 & 198 & 11,446 & 34.0 \\
\hline 7月 & 0 & 10,006 & 1,838 & 2,573 & 1,556 & 261 & 255 & 16,489 & 12.1 \\
\hline 8月 & 0 & 15,844 & 2,224 & 2,818 & 1,704 & 448 & 320 & 23,358 & 2.3 \\
\hline 9月 & 0 & 9,852 & 1,666 & 2,695 & 1,630 & 277 & 245 & 16,365 & 19.5 \\
\hline 10月 & 0 & 3,776 & 908 & 2,695 & 1,630 & 223 & 149 & 9,381 & 59.6 \\
\hline 期間計 & 0 & 49,139 & 8,459 & 16,171 & 9,780 & 1,655 & 1,308 & 86,512 & 22.0 \\
\hline
\end{tabular}

表 5 月別の電力消費量と非蓄熱に対する増加率（仙台）

\begin{tabular}{|c|c|c|c|c|c|c|c|c|c|}
\hline & \multicolumn{2}{|c|}{ 空冷ヒートポンプ } & \multicolumn{2}{|c|}{ 空調機 } & 外調機 & \multicolumn{2}{|c|}{ ポンプ } & \multirow{2}{*}{ 合計 } & \multirow{2}{*}{ 増加率 } \\
\hline & 昼間 & 夜間 & 昼間 & 夜間 & 昼間 & $\begin{array}{l}\text { 昼間 } \\
\end{array}$ & $\begin{array}{l}\text { 夜間 } \\
\end{array}$ & & \\
\hline & kWh & kWh & kWh & kWh & kWh & kWh & kWh & kWh & $\%$ \\
\hline 5月 & 0 & 5,295 & 1,030 & 2,695 & 1,630 & 240 & 172 & 11,062 & 55.7 \\
\hline 6月 & 0 & 7,355 & 1,179 & 2,695 & 1,630 & 244 & 214 & 13,317 & 30.9 \\
\hline 7月 & 141 & 12,830 & 1,787 & 2,573 & 1,556 & 359 & 264 & 19,510 & 10.8 \\
\hline 8月 & 249 & 19,393 & 2,353 & 2,818 & 1,704 & 543 & 334 & 27,394 & 1.2 \\
\hline 9月 & 0 & 12,952 & 1,839 & 2,695 & 1,630 & 339 & 266 & 19,721 & 17.4 \\
\hline 10月 & 0 & 5,781 & 1,234 & 2,695 & 1,630 & 254 & 184 & 11,778 & 34.4 \\
\hline 期間計 & 390 & 63,606 & 9,422 & 16,171 & 9,780 & 1,979 & 1,434 & 102,782 & 17.4 \\
\hline
\end{tabular}

表 6 月別の電力消費量と非蓄熱に対する増加率（東京）

\begin{tabular}{|c|c|c|c|c|c|c|c|c|c|}
\hline & \multicolumn{2}{|c|}{ 空冷ヒートポンプ } & \multicolumn{2}{|c|}{ 空調機 } & 外調機 & \multicolumn{2}{|c|}{ ポンプ } & \multirow{2}{*}{ 合計 } & \multirow{2}{*}{ 増加率 } \\
\hline & 昼間 & 夜間 & 昼間 & 夜間 & 昼間 & 昼間 & 夜間 & & \\
\hline & $\mathrm{kWh}$ & $\mathrm{kWh}$ & $\mathrm{kWh}$ & $\mathrm{kWh}$ & $\mathrm{kWh}$ & $\mathrm{kWh}$ & $\mathrm{kWh}$ & $\mathrm{kWh}$ & $\%$ \\
\hline 5月 & 0 & 8,567 & 1,667 & 2,695 & 1,630 & 297 & 215 & 15,071 & 23.0 \\
\hline 6月 & 0 & 11,516 & 1,956 & 2,695 & 1,630 & 311 & 244 & 18,352 & 17.8 \\
\hline 7月 & 1,274 & 17,746 & 2,333 & 2,573 & 1,556 & 493 & 287 & 26,262 & 2.6 \\
\hline 8月 & 2,925 & 23,800 & 3,532 & 2,818 & 1,704 & 713 & 350 & 35,842 & 4.3 \\
\hline 9月 & 1,160 & 16,780 & 2,328 & 2,695 & 1,630 & 483 & 276 & 25,352 & 7.6 \\
\hline 10月 & 0 & 9,477 & 1,600 & 2,695 & 1,630 & 337 & 213 & 15,952 & 20.4 \\
\hline 期間計 & 5,359 & 87,886 & 13,416 & 16,171 & 9,780 & 2,634 & 1,585 & 136,831 & 9.8 \\
\hline
\end{tabular}

表 7 月別の電力消費量と非蓄熱に対する増加率（鹿児島）

\begin{tabular}{|c|c|c|c|c|c|c|c|c|c|}
\hline & \multicolumn{2}{|c|}{ 空冷ヒートポンプ } & \multicolumn{2}{|c|}{ 空調機 } & \multirow{2}{*}{$\begin{array}{l}\text { 外調機 } \\
\text { 昼間 }\end{array}$} & \multicolumn{2}{|c|}{ ポンプ } & \multirow[b]{2}{*}{ 合計 } & \multirow{2}{*}{ 増加率 } \\
\hline & 昼間 & 夜間 & 昼間 & 夜間 & & 昼間 & 夜間 & & \\
\hline & $\mathrm{kWh}$ & $\mathrm{kWh}$ & $\mathrm{kWh}$ & $\mathrm{kWh}$ & $\mathrm{kWh}$ & $\mathrm{kWh}$ & $\mathrm{kWh}$ & $\mathrm{kWh}$ & $\%$ \\
\hline 5月 & 0 & 10,213 & 1,759 & 2,695 & 1,630 & 284 & 233 & 16,814 & 15.7 \\
\hline 6月 & 51 & 15,166 & 2,206 & 2,695 & 1,630 & 377 & 278 & 22,403 & 9.5 \\
\hline 7月 & 1,300 & 21,893 & 2,687 & 2,573 & 1,556 & 594 & 318 & 30,921 & 4.8 \\
\hline 8月 & 3,850 & 25,967 & 3,397 & 2,818 & 1,704 & 847 & 371 & 38,954 & -1.7 \\
\hline 9月 & 1,363 & 20,042 & 3,248 & 2,695 & 1,630 & 562 & 315 & 29,855 & 7.5 \\
\hline 10月 & 59 & 13,938 & 2,675 & 2,695 & 1,630 & 411 & 249 & 21,657 & 7.8 \\
\hline 期間計 & 6,623 & 107,219 & 15,972 & 16,171 & 9,780 & 3,075 & 1,764 & 160,604 & 5.7 \\
\hline
\end{tabular}

表 8 月別の電力消費量と非蓄熱に対する増加率（東京、高室内発

$$
\text { 熱ケース) }
$$

\begin{tabular}{|c|c|c|c|c|c|c|c|c|c|}
\hline & \multicolumn{2}{|c|}{ 空冷ヒートポンプ } & \multicolumn{2}{|c|}{ 空調機 } & 外調機 & \multicolumn{2}{|c|}{ ポンプ } & \multirow{2}{*}{ 合計 } & \multirow{2}{*}{ 増加率 } \\
\hline & 昼間 & 夜間 & 昼間 & 夜間 & 昼間 & 昼間 & 夜間 & & \\
\hline & $\mathrm{kWh}$ & $\mathrm{kWh}$ & $\mathrm{kWh}$ & kWh & $\mathrm{kWh}$ & $\mathrm{kWh}$ & $\mathrm{kWh}$ & $\mathrm{kWh}$ & $\%$ \\
\hline 5月 & U & 13,051 & 3,090 & 3,607 & 1,630 & 401 & 227 & 22,006 & 20.7 \\
\hline 6月 & 115 & 16,436 & 2,977 & 3,607 & 1,630 & 455 & 249 & 25,469 & 16.1 \\
\hline 7月 & 4,309 & 20,835 & 3,370 & 3,443 & 1,556 & 706 & 286 & 34,505 & 1.7 \\
\hline 8月 & 8,134 & 25,318 & 4,433 & 3,77 & 1,704 & 979 & 341 & 44,680 & 2.9 \\
\hline 9月 & 3,496 & 19,930 & 3,573 & 3,607 & 1,630 & 671 & 276 & 33,183 & 7.5 \\
\hline 10月 & 386 & 13,412 & 3,212 & 3,607 & 1,630 & 466 & 226 & 22,939 & 11.9 \\
\hline & 10 & 08.982 & 65 & 1.6 & 9,78 & 678 & 305 & & \\
\hline
\end{tabular}

表 9 ケース別、月別の蓄熱時間の改善結果

$[\mathrm{h}]$

\begin{tabular}{|c|c|c|c|c|c|}
\hline & 札幌 & 仙台 & 東京 & 鹿児島 & 東京(高室内発熱) \\
\hline 5月 & 1 & 2 & 2 & 2 & 3 \\
\hline 6月 & 2 & 2 & 2 & 3 & 3 \\
\hline 7月 & 2 & 2 & 3 & 3 & 4 \\
\hline 8月 & 3 & 3 & 4 & 4 & 4 \\
\hline 9月 & 2 & 2 & 3 & 3 & 4 \\
\hline 10月 & 1 & 2 & 2 & 3 & 3 \\
\hline
\end{tabular}

表 10 月別の電力消費量と非蓄熱に対する増加率 (東京、高断熱化. 蓄熱時間改善後)

\begin{tabular}{|c|c|c|c|c|c|c|c|c|c|}
\hline & \multicolumn{2}{|c|}{ 空冷ヒートポンプ } & \multicolumn{2}{|c|}{ 空調機 } & 外調機 & \multicolumn{2}{|c|}{ ポンプ } & \multirow{2}{*}{ 合計 } & \multirow{2}{*}{ 増加率 } \\
\hline & 昼間 & 夜間 & 昼間 & 夜間 & 昼間 & 昼間 & 夜間 & & \\
\hline & kWh & kWh & $\mathrm{kWh}$ & $\mathrm{kWh}$ & kWh & $\mathrm{kWh}$ & $\mathrm{kWh}$ & $\mathrm{kWh}$ & $\%$ \\
\hline 5月 & 1,980 & 7,704 & 2,996 & 1,078 & 1,630 & 325 & 129 & 15,842 & 3.0 \\
\hline 6月 & 3,362 & 8,206 & 2,468 & 1,078 & 1,630 & 355 & 138 & 17,237 & 0.8 \\
\hline 7月 & 4,173 & 13,128 & 2,828 & 1,519 & 1,556 & 449 & 196 & 23,849 & 4.4 \\
\hline 8月 & 3,378 & 19,305 & 2,008 & 2,230 & 1,704 & 541 & 301 & 29,467 & -1.3 \\
\hline 9月 & 2,878 & 13,147 & 2,333 & 1,642 & 1,630 & 440 & 201 & 22,271 & -0.3 \\
\hline 10月 & 1,155 & 9,706 & 1,688 & 2,622 & 1,630 & 325 & 246 & 17,372 & 7.3 \\
\hline 期間計 & 16,926 & 71,196 & 14,321 & 10,169 & 9,780 & 2,435 & 1,211 & 126,038 & 1.9 \\
\hline
\end{tabular}

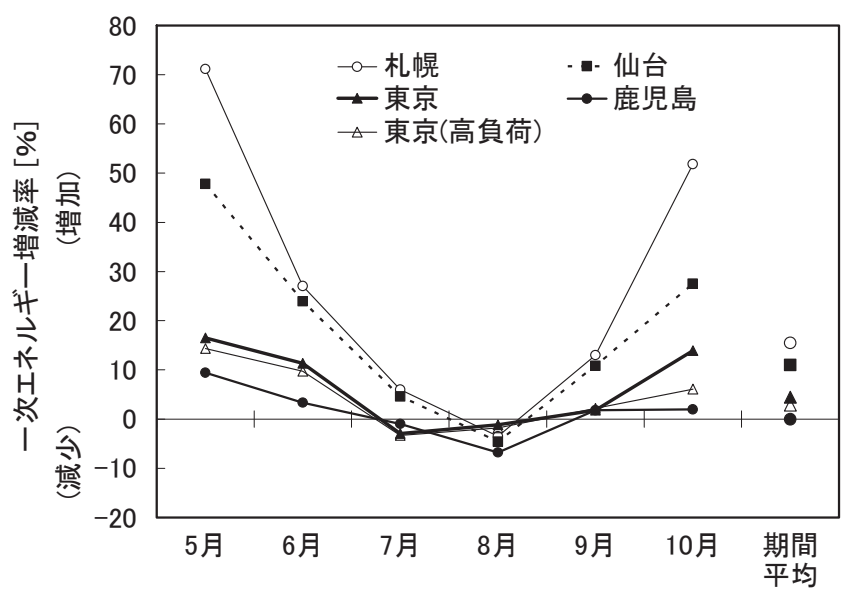

図 11 地域別、月別の一次エネルギー消費量の比較

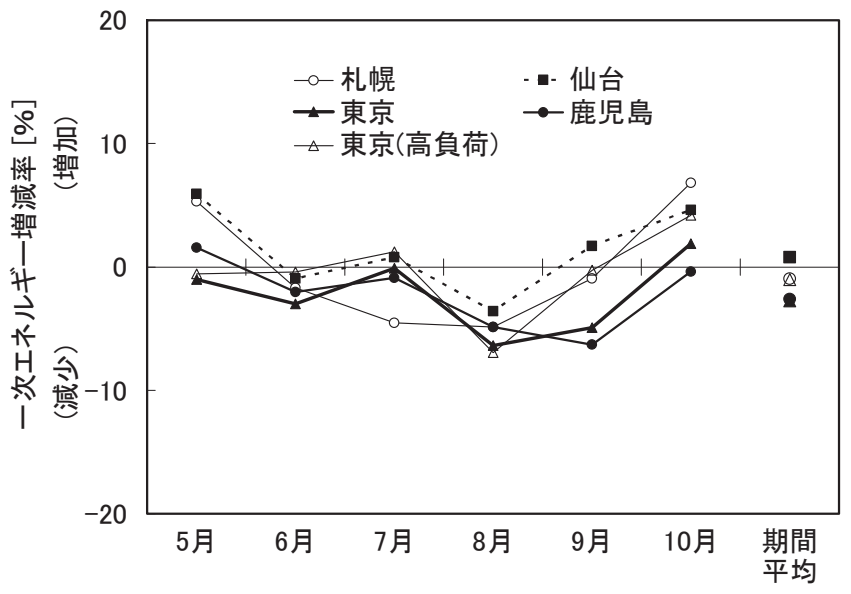

図 12 地域別、月別の一次エネルギー消費量の比較（高断熱化、蓄 熱時間改善後) 


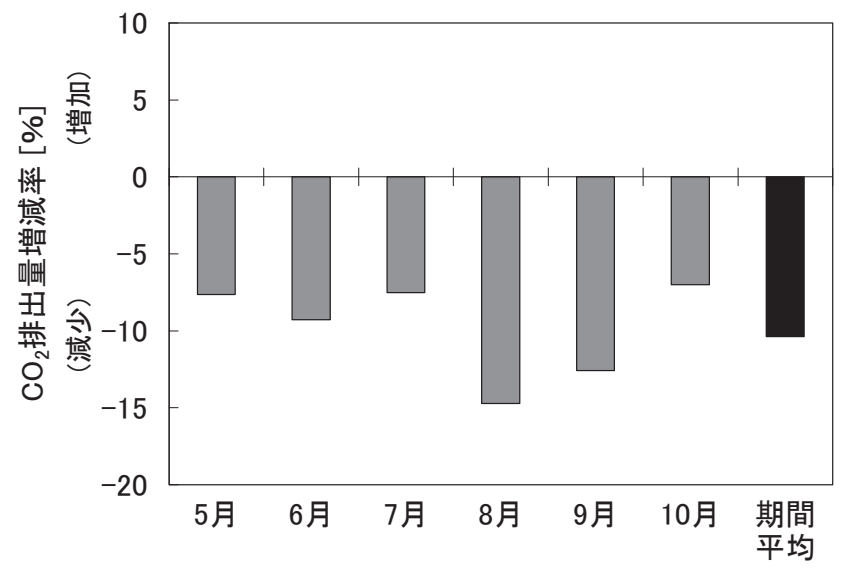

図 13 東京における月別の $\mathrm{CO}_{2}$ 排出量削減率

\section{2 計算結果と環境性の面での考察}

\section{2.1 消費電力量からの検討}

表 4 から表 8 に各ケースの月別、機器別の電力量を昼夜に分けて 集計した結果を示す。表の最後の列は非蓄熱ケースに比べた合計の 増加率である。まず昼夜別の比較では、熱源である空冷ヒートポン プチラーの夜間移行率は高く、冷房期間平均では札幌 $100 \%$ 、仙台 $99.4 \%$ 、東京 $94.2 \%$ 、鹿児島 $94.2 \%$ 、東京の高室内発熱ケース $86.9 \%$ である。また、空冷ヒートポンプチラーの消費用途別稼動割合を見 てみると、ピーク日の合計で夜間の水蓄熱が $41.7 \%$ 、躯体蓄熱が $30.8 \%$ 、昼間の追掛け運転が $27.5 \%$ となっている。これは逆に考え ると全て水蓄熱を行った場合に比べて躯体蓄熱により水蓄熱槽を約 4 割削減できているといえる。

また、空調機などを含めたシステム全体の消費電力量では札幌 $77.0 \%$ 、仙台 $79.1 \%$ 、東京 $77.2 \%$ 、鹿児島 $78.8 \%$ 、東京の高室内発 熱ケース $72.3 \%$ となり、熱源以外の機器の運転も比重も大きい。次 に非蓄熱ケースに比較した電力消費量は前章の空調機負荷でも述心゙ たが、 5 月、 6 月、 10 月の低負荷時、特に札幌、仙台で増加率が高 くなっている。

また、熱源機以外の機器の比重も大きいため、機器別に検討を行 った。機器用途別の割合では、表 6 に示寸東京で熱源 68\%、空気搬 送系 29\%、水搬送系 3\% となっている。増加率では空冷ヒートポン プチラー $2.6 \%$ 、空調機 $48.1 \%$ 、ポンプ $6.2 \%$ となり、特に空調機の 増加率が大きくなっている。これは躯体蓄熱ケースでは単純に空調 機の運転時間が 1.5 倍になるためであり、特に蓄熱時は最大風量で 給気を行うため変風量制御の効果も無いためである。

\section{2.2 環境指標からの検討}

次に省エネ性の検討を行うため、一次エネルギー消費量での比較 を行った。蓄熱を行うことによるメリットの一つに夜間電力のもつ 低環境負荷特性がある。電力の一次エネルギー原単位としては省エ

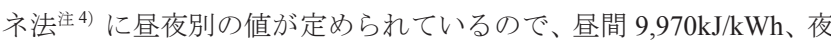
間 9,280kJ/kWh を用いた。図 11 は非蓄熱ケースに比較したケース別、 月別の一次エネルギー消費量の増減率を示している。増減率は一次 エネルギー消費量、および後述の $\mathrm{CO}_{2}$ 排出量とも次式により定義し た。

$$
G=\frac{E-E_{0}}{E_{0}} \times 100
$$

$$
\begin{aligned}
& G: \text { : 非蓄熱ケースに比べた増減率 }[\%] \\
& E_{0}: \text { 非蓄熱ケースの計算結果 } \\
& E: \text { 蓄熱ケースの計算結果 }
\end{aligned}
$$

どのケースでも 8 月は増減率がマイナス(減少)となり、東京、鹿 児島では 7 月もマイナスとなった。室内発熱の密度の点では東京の 高室内発熱ケースで若干の改善が見られた。この図を用いることで、 省エネ性からの躯体蓄熱の運転時期を決定する、あるいは室内環境 と比較して運転可否の判断材料になると考える。

次に躯体蓄熱の効果の改善の検討を行った。まず、躯体蓄熱は建 物の断熱性にも大きく影響を受ける。今回のモデル建物は仕様が多 少古いため、空ガラスを Low-E ペアガラス（熱貫流率 $1.7 \mathrm{~W} / \mathrm{m}^{2} / \mathrm{K}$ 、 反射率 34\%、吸収率 33\%、透過率 33\%）に変更した。また、蓄熱 時間に関しては中間期などの低負荷時に躯体蓄熱 5 時間、水蓄熱 5 時間と寸ることは過大な蓄熱となるので以下の方法で蓄熱時間の改 善を行った。非蓄熱ケースの日空調機負荷が月平均值に最も近い日 を月代表日とし、月代表日の日空調機負荷を全て蓄熱分でまかなえ るように蓄熱時間を再設定した。その際、躯体蓄熱時間と水蓄熱時 間の比率の設定は様々考えられるが、今回はその一例として同時間 とした。表 9 にケース別、月別に蓄熱時間の改善を検討した結果を 示す。これらの条件をもとにシミュレーションを行った結果が、東 京での電力消費量が表 10、一次エネルギー増減率をまとめたものが 図 12 である。これによると冷房期間の平均で、仙台以外で増減率が マイナスとなった。また、東京では期間平均で $2.7 \%$ 削減、 5 月から 9 月まで増減率がマイナスとなり高断熱化と蓄熱時間の改善の効果 が高いことがわかった。

最後に $\mathrm{CO}_{2}$ 排出量の点で検討を行った。電力の $\mathrm{CO}_{2}$ 排出量の昼夜 別原単位は法的な值は与えられていないが、東京電力の 2001 年度の 実測結果が発表 7) されているので、その值を使って検討を行った。 昼間 $0.338 \mathrm{~kg}-\mathrm{CO}_{2} / \mathrm{kWh}$ 、夜間 $0.276 \mathrm{~kg}-\mathrm{CO}_{2} / \mathrm{kWh}$ である。ただし、 $\mathrm{CO}_{2}$ 排出原単位は電力会社毎に異なるので、東京の検討のみとした。ま た、ケースとしては高断熱化、蓄熱時間を改善した結果を用いた。 図 13 は月別の $\mathrm{CO}_{2}$ 排出量の増減率である。一次エネルギー消費量 の結果に比べて、蓄熱による削減効果は高くなっている。増減率は 冷房期間を通じてマイナス(減少)であり、冷房期間の平均で 10.4\% 減少となった。

\section{5.まとめ}

本論文では水蓄熱を組み合わせた躯体蓄熱システムに関し、二次 側空調機から熱源まで空調システム全体での期間シミュレーション を行い、地域別、月別の特性の評価を行った。また、昼夜別の電力 原単位を用いて躯体蓄熱による夜間電力利用の効果の評価を行い、 各種指標より躯体蓄熱運転時期について検討を行った。さらに建物 の断熱性能、月別の蓄熱時間の改善に関する検討を行った。以下に 本論文で得られた知見をまとめる。

1) 水蓄熱との組み合わせの点では、設定条件にもよるが今回の検討 
では、全て水蓄熱を行った場合に比べて躯体蓄熱により約 4 割の 水蓄熱槽が削減できると考えられる。

2) 断熱性の良くない建物でフルに蓄熱を行う場合は、空調機負荷、 電力消費量とも冷房負荷の小さくなる 5 月、6月、10月で非蓄熱 ケースに比べて大きくなる傾向がある。特に札幌、仙台ではこの 時期の増加率が高く、これらの地域ではこの時期躯体蓄熱を行う ことは不利と考えられる。

3) 高断熱化と月別の蓄熱時間の改善を行った場合、非蓄熱ケースに 比べた電力消費量の増加率、一次エネルギー増減率とも大きな改 善が見られた。東京では期間平均で $2.7 \%$ 削減、 5 月から 9 月まで 一次エネルギー増減率がマイナス(減少)となり省エネの面での躯 体蓄熱の有効性が示された。

4) $\mathrm{CO}_{2}$ 排出量の点では東京の結果より、増減率は冷房期間を通じて マイナス(減少)であり、冷房期間の平均で 10.4\%減少となった。 電力の $\mathrm{CO}_{2}$ 排出原単位の值にもよるが、 $\mathrm{CO}_{2}$ 排出量の点では一次 エネルギー消費量による評価よりも削減効果が期待できる。

\section{参考文献}

1) 長井達夫 : 躯体の熱容量を利用した動的最適化空調運転がエネルギー消 費特性に及ぼす影響について、日本建築学会計画系論文集、第 540 号、 pp.45-52、2001.2

2) 盧炫佑、宇田川光弘 : 身体蓄熱空調システム性能のシミュレーションに よる検討、日本建築学会計画系論文集、第 544 号、pp.31-38、2001.6

3) 相楽典泰、三浦克弘 : 躯体蓄熱と氷蓄熱ビル用マルチを組み合わせた 4 つの空調方式におけるエネルギ一性能比較、日本建築学会環境系論文集、
第 600 号、pp.29-37、2006.2

4) 滝沢博 : 標準問題の提案(オフィス用標準問題)、第 15 回熱シンポジウム テキスト、日本建築学会環境工学委員会熱分科会、pp.35-42、1985

5) 武田清香、長野克則、持田徹、中村卓司 : 粒状潜熱蓄熱材を適用した躯 体蓄熱床吹出し空調システムに関する研究(その 2 : システムのモデル化 と空調機負荷の夜間移行効果)、日本建築学会環境系論文集、第 584 号、 pp.47-52、2004.10

6) (財)環境建築・省エネルギー機構 : 建築物の省エネルギー基準と計算の 手引き（平成 15 年度版）、改定 10 版、2003.10

7) 古森秋文、塚田裕二 : 系統電力の環境性に関する考察、空気調和・衛生 工学会学術講演会講演論文集、pp.1233-1235、2002.9

\section{注}

注 1) 蓄熱投入熱量比率とは躯体蓄熱日の躯体蓄熱量を、同一日の夜間投入 熱量で除した比率。 蓄熱投入熱量比率 $[\%]=($ 身体蓄熱量 $) /($ 夜間投入熱量 $) \times 100$

注 2) 蓄熱効率とは非蓄熱日に比べた躯体蓄熱日の昼間の空調機負荷積算值 の削減量を夜間投入熱量で除した比率。

蓄熱効率 $[\%]=\{($ 非蓄熱日の昼間の空調機負荷積算値 $)-($ 躯体蓄熱日の 昼間の空調機負荷積算值 $)\} /($ 夜間投入熱量 $) \times 100$

注 3) ピークシフト率とは非蓄熱日に比べて、蓄熱以外の条件が同じ躯体蓄 熱日において、昼間の空調機負荷の積算值がどれだけ削減されたかを 表す比率。

ピークシフト率 $[\%]=\{1-($ 躯体蓄熱日の昼間の空調機負荷積算值) $/$ (非蓄熱日の昼間の空調機負荷積算伹) $\} \times 100$

注 4) エネルギーの使用の合理化に関する法律

（2009年 7 月 10 日原稿受理，2009年12月10日採用決定） 